\title{
The Neurosteroid 3 $\alpha$-Hydroxy-5 $\alpha$-Pregnan-20-One Induces Cytoarchitectural Regression in Cultured Fetal Hippocampal Neurons
}

\author{
Roberta Diaz Brinton \\ Department of Molecular Pharmacology and Toxicology, University of Southern California Pharmaceutical Sciences \\ Center, Los Angeles, California 90033
}

The neurosteroid $3 \alpha$-hydroxy-5 $\alpha$-pregnan-20-one (3 $\alpha, 5 \alpha$-THP) acts as a potent allosteric modulator and a direct activator of the GABA-chloride channel complex. This neurosteroid has also been found to protect against seizures that arise from blockade of the GABA-chloride channel complex. Because $3 \alpha, 5 \alpha$-THP protects against excitotoxin-induced seizure activity and because seizure activity has been found to be associated with aberrant hippocampal nerve cell growth, the rapid effect of the neurosteroid $3 \alpha, 5 \alpha$-THP upon nerve cell growth was investigated using videomicroscopy of hippocampal neurrons in culture. Within $\mathbf{4 0}$ min of exposure $3 \alpha, 5 \alpha-$ THP induced a significant decrease in the area and length of neurites. A concomitant decrement in the number and length of filopodia decorating neuritic extensions also occurred within the $\mathbf{4 0}$ min of $\mathbf{3} \alpha, 5 \alpha-$ THP exposure. Both rapid and slow retrograde movement of intracellular organelles was observed in $3 \alpha, 5 \alpha$-THP-treated neurons. $3 \alpha, 5 \alpha$-THPinduced regression of neuritic extensions occurred only in nerve cells that had not yet established contact with other nerve or glial cells in culture. Established structural connections between neurons or glia did not erode during $3 \alpha, 5 \alpha-$ THP exposure. Neither the inactive stereoisomer $3 \beta$-hydroxy-5 $\beta$-pregnan-20-one nor progesterone had a significant effect upon any of the morphological parameters assessed. In approximately $25 \%$ of the cells in which $3 \alpha, 5 \alpha-$ THP had induced regression, subsequent exposure to $17 \beta$-estradiol induced profuse filopodial growth within $60 \mathrm{sec}$ of exposure. In cultures similar in age to those used in the morphological studies, $3 \alpha, 5 \alpha$-THP induced a significant increase in ${ }^{36} \mathrm{Cl}^{-}$ uptake within 10 sec. The magnitude of ${ }^{36} \mathrm{Cl}-$ uptake was comparable to that induced by exposure to $100 \mu \mathrm{M}$ GABA. In older, more mature cultures in which the nerve cells had established structural connections, $3 \alpha, 5 \alpha$-THP protected cells from picrotoxin-induced nerve cell death. These results demonstrate that $3 \alpha, 5 \alpha$-THP can induce regression of neuronal morphology within a relatively rapid time frame. $3 \alpha, 5 \alpha-$ THP induction of ${ }^{36} \mathrm{Cl}^{-}$uptake within $10 \mathrm{sec}$ suggests that

\footnotetext{
Received May 28, 1993; revised Sept. 22, 1993; accepted Oct. 26, 1993.

I express my gratitude to Dr. Anthony van den Pol for generous assistance and advice during the early stages of this work and to Dr. David Lavond for advice and assistance in statistical analysis of the data. The excellent technical assistance of Corrine Hyman is also acknowledged. This work was supported by BRSG Funds 2 S07 RR 05792-13 awarded to University of Southern California School of Pharmaceutical Sciences and by a University of Southern California Faculty Innovative Research Award awarded to R.D.B.

Correspondence should be addressed to Roberta Diaz Brinton, Department of Molecular Pharmacology and Toxicology, University of Southern California Pharmaceutical Sciences Center, 1985 Zonal Avenue, Los Angeles, CA 90033.

Copyright @ 1994 Society for Neuroscience $0270-6474 / 94 / 142763-12 \$ 05.00 / 0$
}

activation of neurosteroid-regulated chloride channels is an initial step in the biochemical mechanism underlying the retraction induced by this progesterone metabolite steroid. In select instances, $17 \beta$-estradiol induced an extremely rapid reversal of the filopodial regression produced by $3 \alpha, 5 \alpha$-THP. Collectively, these findings indicate that steroid factors acting singly and in combination can induce significant changes in nerve cell morphology within a time frame that is consistent with $3 \alpha, 5 \alpha-$ THP and $17 \beta$-estradiol regulation of excitability.

[Key words: neurosteroids, progesterone metabolite steroids, nerve cell growth, hippocampal neurons, epilepsy, estrogen]

Recent discoveries in the field of neurosteroids have led to a resurgence of research efforts to better understand the influence of steroids acting at membrane receptors on CNS function (Harrison and Simmonds, 1984; Barker et al., 1986; Majewska et al., 1986; Gee et al., 1987, 1988; Harrison et al., 1987; Lambert et al., 1987; Morrow et al., 1987, 1990; Gee, 1988; Turner et al., 1989; Purdy et al., 1990; reviewed in Paul and Purdy, 1992). These recent discoveries are based on the now classical work of Selye $(1941,1942)$, who observed anesthetic effects of the steroids progesterone and corticosterone.

Results from several laboratories have shown that glial cells in the brain are capable of de novo synthesis of select steroids (Weidenfeld et al., 1980; Holzbauer et al., 1985; Hu et al., 1987; Jung-Testas et al., 1989a,b; Krieger and Scott, 1989; Baulieu and Robel, 1990; Karavolas and Hodges, 1990, 1991). These findings lead Baulieu, Robel, and colleagues to propose the concept of neurosteroids (Le Goascogne et al., 1987; Jung-Testas et al., 1989). Specifically, these investigators observed that glial cells were capable of cholesterol, progesterone, and pregn-5-ene$3 \beta, 20 \alpha$-diol synthesis. They further found the conversion of progesterone into the metabolites pregnane-3,20-dione and $3 \alpha$ hydroxy-5 $\alpha$-pregnan-20-one ( $3 \alpha, 5 \alpha$-THP). Most recently, it has been found that accumulation of $3 \alpha, 5 \alpha$-THP can reach levels as high as $30 \mathrm{ng} / \mathrm{ml}$ in pregnant rats (Paul and Purdy, 1992).

Biochemical and electrophysiological studies performed during the same time frame indicated that metabolites of progesterone could directly induce chloride flux at micromolar concentrations and at lower concentrations could act as an allosteric modulator of GABA-mediated chloride ion conductance (Harrison and Simmonds, 1984; Majewski et al., 1986; Gee et al., 1987, 1988; Harrison et al., 1987; Lambert et al., 1987; Morrow et al., 1987; reviewed in Gec, 1988). Collcctively, results of these studies have shown that the naturally occurring metabolite of 
progesterone, $3 \alpha, 5 \alpha-$ THP, and the naturally occurring metabolite of deoxycorticosterone, $3 \alpha, 21$-dihydroxy-5 $\alpha$-pregnan-20one, can directly interact with receptors to regulate chloride channel activity in a GABA-dependent manner at low concentrations and in a GABA-independent manner at higher concentrations.

Because $3 \alpha, 5 \alpha$-THP had been shown to enhance chloride conductance through the GABA-chloride channel complex and because this complex has been implicated in the control of epilepsy, the ability of $3 \alpha, 5 \alpha$-THP to protect against seizure activity was investigated. Results of these studies showed that $3 \alpha, 5 \alpha-$ THP protected against chemically induced seizures at concentrations that were more potent than either benzodiazepines or barbiturates (Gee et al., 1988; Paul and Purdy, 1992).

A correlative relationship between seizure activity and change in nerve cell morphology has been reported. Several laboratories have found aberrant growth of hippocampal circuitry following kindling-induced seizures (Tauck and Nadler, 1985; Cronin and Dudek, 1988; Geinisman et al., 1988; Sutula et al., 1988; Represa et al., 1989; Ben Ari and Represa, 1990). Mossy fiber sprouting was found both in postmortem brain tissue derived from children who suffered with childhood epilepsy (Represa et al., 1989) as well as in surgically derived tissue samples from human adults (reviewed in Ben Ari and Represa, 1990). Collectively, these results strongly suggest that seizure activity results in aberrant nerve cell growth.

Bccausc scizurc activity is associated with abcrrant nerve cell growth and since $3 \alpha, 5 \alpha$-THP protects against seizure activity, the hypothesis that $3 \alpha, 5 \alpha$-THP would inhibit nerve cell growth was formulated. Experiments to test this hypothesis utilized videomicroscopy to monitor cytoarchitectural changes of individual nerve cells following exposure to $3 \alpha, 5 \alpha$-THP. Results of this study demonstrated that $3 \alpha, 5 \alpha$-THP induced neurite and filopodial regression within a time frame that is consistent with its seizure-suppressive effects, that $3 \alpha, 5 \alpha$-THP induced chloride uptake into cultured hippocampal neurons, that $3 \alpha, 5 \alpha$-THP protected against picrotoxin-induced nerve cell death, and that, in select instances, $17 \beta$-estradiol reversed the regressive effect of $3 \alpha, 5 \alpha$-THP.

\section{Materials and Methods}

Culture preparation. Hippocampal cultures were prepared as described by Bartlett and Banker (1984). Briefly, hippocampi were dissected from the brains of embryonic day 18 (E18) rat fetuses, treated with $0.25 \%$ trypsin in serum-containing media for $15 \mathrm{~min}$ at room temperature, and dissociated by repeated passage through a series of fire-polished constricted Pasteur pipettes. Between 20,000 and 40,000 cells were seeded onto polylysine-coated $(10 \mu \mathrm{g} / \mathrm{ml})$ coverslips ( $22 \mathrm{~mm}$ in diameter). Nerve cells were grown in phenol red-free Dulbecco's Modified Eagle's Medium (DMEM; GIBCO) supplemented with $10 \mathrm{~mm} \mathrm{NaHCO}_{3}, 5$ $\mathrm{U} / \mathrm{ml}$ penicillin and $5 \mu \mathrm{g} / \mathrm{ml}$ streptomycin (GIBCO), 10\% F12 nutrient medium (GIBCO), and 10\% fetal calf serum (GIBCO). Medium was phenol red free since it has been shown that phenol red can act as an estrogen agonist in culture (Berthois et al., 1986). Nerve cells were used following $1-4 \mathrm{~d}$ in culture.

Preparation of steroids. Steroids (Steraloids, Inc.) were dissolved in $100 \%$ dimethyl sulfoxide (DMSO) and diluted in serum-containing culture media to desired concentration. Final concentration of DMSO added to the cultures was $0.01 \%$, a concentration that had no effect upon nerve cell growth.

Observations of living nerve cells. Nerve cells attached to polylysinecoated coverslips were removed from the culture dish and rapidly mounted into a perfusion chamber. Media exchange took place every $10 \mathrm{~min}$. Steroid-containing medium was added at the end of the $20 \mathrm{~min}$ equilibration period. Volume of the chamber was $200 \mu \mathrm{l}$ and complete media exchange was accomplished within $30 \mathrm{sec}$; $\mathrm{pH}$ was maintained at 7.4 .
Videomicroscopic recording of individual living nerve cells was accomplished using a Dage-MTI camera equipped with a Newvicon tube linked to an Olympus BH-2 microscope and a Panasonic time-lapse video recorder (model AG-6050). Recordings were made using phasecontrast optics with a $100 \times$ objective and a 1.25 or 1.5 multiplier with $100 \mathrm{~W}$ tungsten source passed through a green filter. Recordings occurred between 24 and $96 \mathrm{hr}$ following seeding of the culture.

Morphological and statistical analysis of cytoarchitectural data. Morphological analysis was achieved using a BioQuant Image Analysis system, which permitted quantitation of length, area, and total number of filopodial extensions. Statistically significant differences were determined by a mixed-design analysis using a repeated-measures ANOVA for within groups, followed by an ANOVA for between groups, followed by a Newman-Keuls post hoc analysis. Potential bias in selection of nerve cells to receive experimental treatment was evaluated by a comparative analysis between filopodial length of control and $3 \alpha, 5 \alpha-\mathrm{THP}-$ treated neurites. Filopodial length was chosen because this morphological parameter is uniformly distributed independent of cell type, whereas neurite or branch length is highly dependent upon cell type. Statistical analysis of filopodial length $(7.4 \pm 0.6 \mu \mathrm{m}, n=144)$ at time 0 of control neurites and filopodial length $(7.5 \pm 0.7 \mu \mathrm{m}, n=144)$ at time 0 of $3 \alpha, 5 \alpha$-THP-treated neurites revealed no significant difference $(p<0.98)$ between the groups. This result indicates that bias was not introduced into the selection of neurons for experimental treatment. Moreover, analysis for statistically significant differences based on a change from original length or number obviates any contribution of intrinsic morphological limits determined by cell type. Prior to pooling the data obtained with $250 \mathrm{nM}$ and $1 \mu \mathrm{M} 3 \alpha, 5 \alpha$-THP, a Student's $t$ test was performed. Results of this analysis indicated no significant difference between the magnitude of response of neurites treated with $250 \mathrm{~nm}$ and $1 \mu \mathrm{M}$ THP in either neurite area $(p<0.18)$, neurite length $(p<0.65)$, or number of filopodia $(p<0.31)$. Thus, the data obtained from the two concentrations were pooled.

${ }^{36} \mathrm{Cl}^{-}$uptake. Cultures were prepared as described above with the exception that cells were seeded onto polylysine-coated $(10 \mu \mathrm{g} / \mathrm{ml})$ plastic coverslips $\left(22 \times 22 \mathrm{~mm}\right.$, Arthur $\mathrm{H}$. Thomas). ${ }^{36} \mathrm{Cl}^{-}$uptake combined the strategies described in Thampy and Barnes (1984) and Suzdak et al. (1986). Briefly, neurons were cultured for $3 \mathrm{~d}$ in media described above. Coverslips were removed from tissue culture medium and incubated at $37^{\circ} \mathrm{C}$ for $15 \mathrm{~min}$ in fresh DMEM-free medium saturated with a $5 \% \mathrm{CO}_{2} / 95 \%$ air mixture. Coverslips were then rinsed for $3-4 \mathrm{sec}$ at room temperature in Tris-HEPES-buffered saline ( $\mathrm{pH} 7.4$ ) containing $145 \mathrm{~mm} \mathrm{NaCl}, 5 \mathrm{~mm} \mathrm{KCl}, 1 \mathrm{~mm} \mathrm{MgCl}_{2}, 1 \mathrm{~mm} \mathrm{CaCl}$, and $10 \mathrm{~mm}$ $d$-glucosc. Immediatcly after the rinse the coverslips were drained on tissue paper and then transferred to Tris-HEPES-buffered saline containing ${ }^{36} \mathrm{Cl}^{-}, 0.96 \mu \mathrm{Ci} / \mathrm{ml}, 100 \mu \mathrm{M}$ GABA (Sigma), or $1 \mu_{\mathrm{M}} 3 \alpha, 5 \alpha-\mathrm{THP}$. After $10 \mathrm{sec}$ incubation at room temperature with ${ }^{36} \mathrm{Cl}^{-}$and experimental substances, uptake was terminated by rapid transfer of the coverslip to ice-cold Tris-HEPES buffer containing $100 \mu \mathrm{M}$ picrotoxin (Sigma) and rinsed $3 \times 2 \mathrm{sec}$ in picrotoxin-containing buffer. Coverslips were transferred to scintillation vials containing $1 \mathrm{ml}$ of $0.5 \mathrm{NaOH}$ and incubated at room temperature for $4 \mathrm{hr}$. A $200 \mu$ laliquot was withdrawn for protein determination using the Pierce Protein Assay Reagent (Rockford, IL), and scintillation fluid added to the remaining $800 \mu$ l of sample for scintillation counting. Data are expressed as $\mathrm{nmol}{ }^{36} \mathrm{Cl}^{-} / \mu \mathrm{g}$ protein and were analyzed for significant differences using a Student's $t$ test.

Cytotoxicity. Hippocampal nerve cell cultures were treated for $15 \mathrm{hr}$ with either $1 \mathrm{mM}$ picrotoxin (Sigma), $1 \mu \mathrm{M} 3 \alpha, 5 \alpha$-THP, or a combination of $1 \mathrm{mM}$ picrotoxin and $1 \mu \mathrm{M} 3 \alpha, 5 \alpha$-THP. Picrotoxin was dissolved in serum-containing media while $3 \alpha, 5 \alpha$-THP was first dissolved in DMSO and diluted in serum-containing media to desired concentration. The final concentration of DMSO in the culture was $0.01 \%$, a concentration that had no effect on nerve cell growth. Control cultures were treated with serum-containing media with $0.01 \%$ DMSO. Cell death determination was achieved by counting trypan blue-positive nerve cells using phase-contrast microscopy at $40 \times$ magnification. A one-way ANOVA followed by a Newman-Keuls post hoc analysis was used to determine significant differences between the groups.

\section{Results}

General features of $3 \alpha, 5 \alpha-T H P$ responsivity

The effect of $3 \alpha, 5 \alpha$-THP ( $1 \mu \mathrm{M})$ upon neurite growth was evident in most neurites tested, in that $70 \%$ of the ncurites obscrved showed responsivity. The percentage of $3 \alpha, 5 \alpha$-THP-responsive 
Tahle 1. Steroid specificity of effects upon parameters of nerve cell growth

\begin{tabular}{llll} 
Condition & Neurite area $(\mu \mathrm{m})$ & Neurite length $(\mu \mathrm{m})$ & Number of filopodia \\
\hline Control & $-3.38 \pm 3.17(18)$ & $-1.76 \pm 0.83(20)$ & $-0.95 \pm 0.50(20)$ \\
$3 \beta, 5 \beta$-THP & $-5.53 \pm 12.58(30)$ & $-1.95 \pm 0.75(30)$ & $-2.47 \pm 0.66(30)$ \\
Progesterone & $-9.10 \pm 8.03(22)$ & $-1.64 \pm 1.25(22)$ & $-2.82 \pm 1.03(22)$
\end{tabular}

All data are expressed as change from baseline value at end of $40 \mathrm{~min}$ observation period for each experimental condition.

Values represent mean $\pm \operatorname{SEM}(n=$ number of neurites analyzed).

neurons remained consistent throughout and across days in culture, up to $4 \mathrm{~d}$. Morphological characteristics in culture were not a predictive measure of which cell type would be responsive. Thus, even though a cell would have many of the hallmark morphological characteristics of a hippocampal pyramidal cell, these cytoarchitectural qualities did not serve as a consistent marker of $3 \alpha, 5 \alpha$-THP responsivity. Neurites that were in an active growth phase as well as neurites that appeared to be in a quiescent growth state exhibited $3 \alpha, 5 \alpha$-THP responsivity. Moreover, the responsivity of one neuritic extension on a nerve cell usually but not always was associated with retraction in the other neuritic extensions of the same neuron. Lastly, both morphologically determined axons and dendrites showed $3 \alpha, 5 \alpha-$ THP responsivity.

\section{$3 \alpha, 5 \alpha-T H P$ influences upon morphological characteristics of neuritic extensions}

Neurite area of $3 \alpha, 5 \alpha$-THP-treated neurons showed a significant decrease in total area within $20 \mathrm{~min}$ of exposure to the steroid $[F=5.25$; df 2, 76; $p<0.007]$ (Figs. 1, 2). Moreover, the decrement in neurite area at 30 and 40 min was significantly greater than that which was apparent at $20 \mathrm{~min}$. Reduction of neurite area appears to reach maximum hetween 30 and 40 min since the loss in area at $40 \mathrm{~min}$ was not significantly greater than that which occurred at $30 \mathrm{~min}$. Neurite area in control neurons did not change significantly during the 40 min observation period.

A significant decrement in neurite length also occurred in response to $40 \mathrm{~min}$ exposure to $3 \alpha, 5 \alpha$-THP [ $F=5.67$; df 2, 80; $p<0.004$ ] (Figs. 1, 3). As with neurite area, the loss in neurite length at 40 min was significantly greater than that which occurred following $20 \mathrm{~min}$ exposure to $3 \alpha, 5 \alpha$-THP (Fig. 3). Retraction of the neurite shown in Figure 1 indicates that largescale retraction is associated with cytoplasmic regression toward the cell body while the cytoskeletal fibers remain intact. This response suggests the potential for reversal of neurite retraction. Control neurites cxhibitcd no significant change in neurite length during the $40 \mathrm{~min}$ observation period.

In response to $3 \alpha, 5 \alpha$-THP, the number of filopodia/neurite decreased significantly $[F=6.09$; df $2,80, p<0.003]$ within $40 \mathrm{~min}$ (Fig. $4 A$ ). Similar to the decrease in neurite area and length, the loss in number of filopodia at $40 \mathrm{~min}$ was significantly greater than that which occurred following $20 \mathrm{~min}$ exposure to $3 \alpha, 5 \alpha$-THP (Fig. 4A). Filopodial length also decreased significantly following $40 \mathrm{~min}$ exposure to $3 \alpha, 5 \alpha$-THP $\left(^{*}, p<0.02\right.$, Fig. $4 B$ ). In control neurites, the number of filopodia decorating neurites tended to also decrease, but not significantly (1 filopodium $/ 40 \mathrm{~min}$; Fig. $4 A$ ), while the length of the remaining flopodia increased during the $40 \mathrm{~min}$ observation period $(0.7$ $\mu \mathrm{m} \pm 0.3$; Fig. $4 B$ ).

In a number of cells studied, one neurite had established a physical contact with a neurite from an adjacent cell. In these instances, treatment with $3 \alpha, 5 \alpha-$ THP did not induce an erosion of the established structural contact. This observation was confirmed in a separate series of experiments described below that examined the ability of $3 \alpha, 5 \alpha$-THP to protect against picrotoxin-induced cell death. In these experiments, cells were treated with $1 \mu \mathrm{M} 3 \alpha, 5 \alpha$-THP for $24 \mathrm{hr}$ without evidence of erosion of structural connections between neurons and or glial cells. Interestingly, a structural contact at one neurite did not preclude the responsivity of other unconnected neurites to the regressive effect of $3 \alpha, 5 \alpha$-THP.

\section{Mobility of intracellular phase-dense bodies in dendrites and axons}

As seen in Figure 1, many phase-dense bodies (PDBs) are apparent throughout the extent of the neurite. PDBs were frequently apparent in both control and $3 \alpha, 5 \alpha$-THP-treated neurites under study. However, movement of PDBs was most apparent in $3 \alpha, 5 \alpha$-THP-treated neurites. PDBs, ranging in size between 2.1 and $4.8 \mu \mathrm{m}^{2}$, could be observed traversing the entire length of the neurite by rapid saltatory and bidirectional movements at a rate between 1.8 and $0.60 \mu \mathrm{m} / \mathrm{sec}$. PDBs also exhibited merger with larger PDBs while other PDBs would merge and then reemerge from such a union. During the evacuation of the cytoplasmic compartment of the neurite, the PDBs accumulated into large masses that underwent slower retrograde movement toward the cell body $(1.42 \mu \mathrm{m} / \mathrm{min}$; Fig. 1). PDB movement was also apparent in $3 \alpha, 5 \alpha$-THP-treated neurites that had contacted other cells. In these instances, PDBs continued to be rapidly motile but did not undergo retrograde movement away from the site of structural contact.

\section{Steroid specificity}

The stereoisomer of $3 \alpha, 5 \alpha$-THP, $3 \beta$-hydroxy-5 $\beta$-pregnan-20-

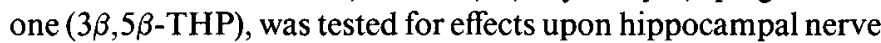
cell growth. This stereoisomer $3 \beta, 5 \beta$-THP had no significant effect upon any of the morphological parameters assessed $(n=$ 30 neurites). Similarly, neurites $(n=22)$ treated with progesterone for $40 \mathrm{~min}$ showed no significant change in morphology (see Table 1).

\section{$3 \alpha, 5 \alpha-T H P$ effects on ${ }^{36} \mathrm{Cl}^{-}$uptake}

Addition of $3 \alpha, 5 \alpha$-THP ( $1 \mu \mathrm{M}$, the same concentration used in the morphological studies) induced a significant $(p<0.01)$ increase in ${ }^{36} \mathrm{Cl}^{-}$uptake above basal following a $10 \mathrm{sec}$ exposure (Fig. 5). GABA $(100 \mu \mathrm{M})$ also induced a significant increase in ${ }^{36} \mathrm{Cl}^{-}$uptake above basal but was less in magnitude than the uptake induced by $3 \alpha, 5 \alpha$-THP. In an attempt to determine whether ${ }^{36} \mathrm{Cl}^{-}$uptake persisted over the 40 min $3 \alpha, 5 \alpha$-THP exposure as in the morphological studies, ${ }^{36} \mathrm{Cl}^{-}$uptake was measured following a $40 \mathrm{~min}$ exposure to $3 \alpha, 5 \alpha$-THP. Results of this study revealed that $1 \mu \mathrm{M} 3 \alpha, 5 \alpha$-THP-treated cultures were not significantly different $(3.9 \pm 0.44 \mathrm{nmol} / \mu \mathrm{g}$ protein, $n=12$; 

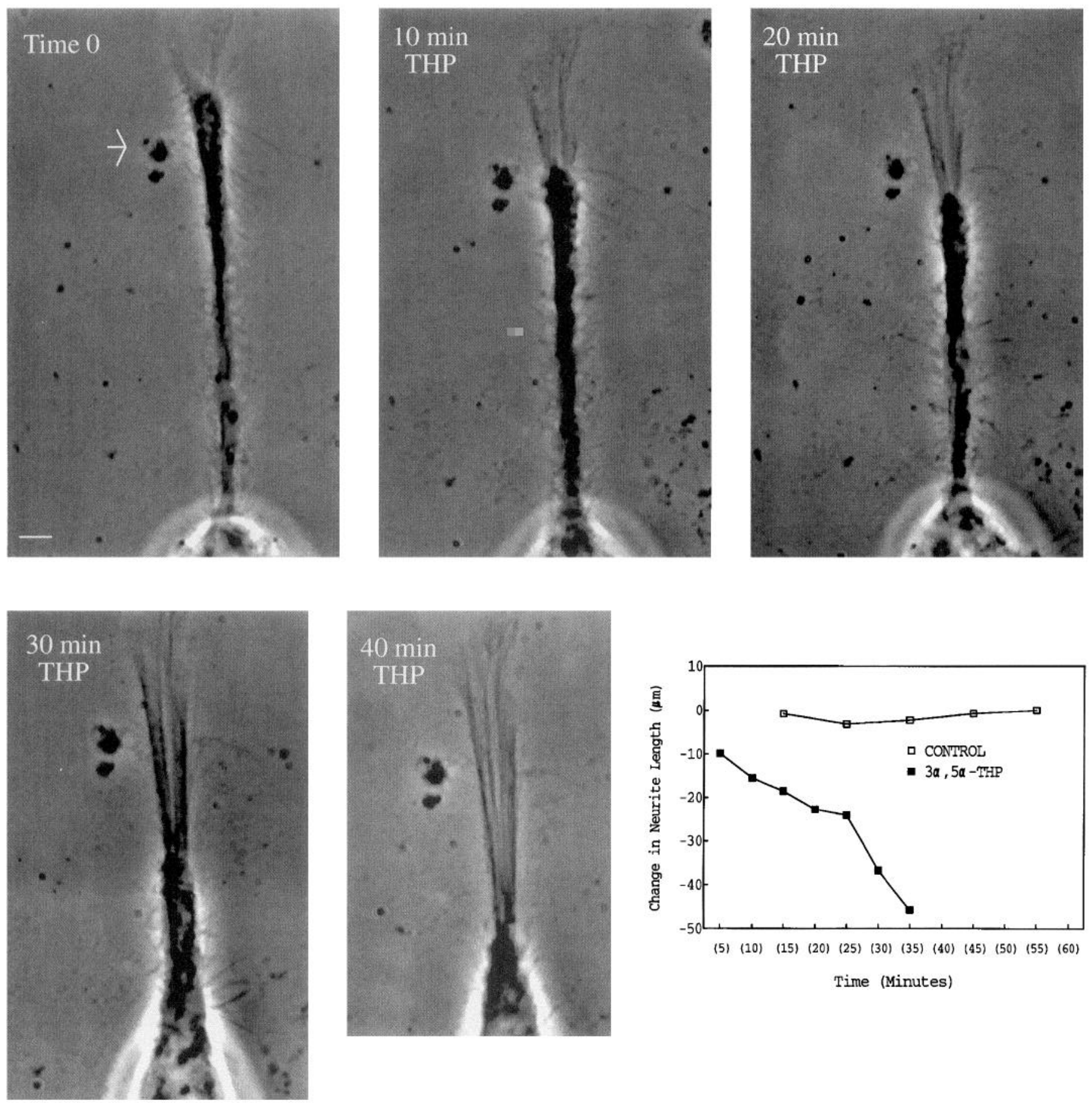

(5) (10) (15) (20) (25) (30) (35) (40) (45) (50) (55) $(60)$

Time (Minutes)

Figure 1. Photomicrograph of a hippocampal nerve cell neurite prior to (Time 0 ) and during 10, 20,30, and 40 min of exposure to $1 \mu \mathrm{M} 3 \alpha, 5 \alpha$ THP. The relative time of recording (in min) of the same neurite is denoted in the upper left corner of each panel. A cluster of debris marked by the white arrow serves as an invariant reference point. Criterion for photo composition was inclusion of the tip of the cytoskeleton of the neurite to the cell body. Thus, Time 0,10 , and $20 \mathrm{~min}$ are composites of three photographs, while $30 \mathrm{~min}$ is a composite of two photographs and $40 \mathrm{~min}$ is a single photograph. To maintain the same magnification for all images, 30 and $40 \mathrm{~min}$ images are shorter in length and consistent with regression of the cytoplasmic domain of the neurite back to the cell body. Lower right panel indicates the rate of neurite regression (1.4 $\mu \mathrm{m} / \mathrm{min})$. Scale bar, $5 \mu \mathrm{m}$.

$p<0.5)$ from basal ${ }^{36} \mathrm{Cl}^{-}$uptake $(4.32 \pm 0.53 \mathrm{nmol} / \mu \mathrm{g}$ protein, $n=8$ ). These results indicate that ${ }^{36} \mathrm{Cl}^{-}$uptake is not constant during the $40 \mathrm{~min}$ exposure to $3 \alpha, 5 \alpha$-THP and that mechanisms for chloride extrusion from the cell operated effectively during the $40 \mathrm{~min}$ of exposure to $3 \alpha, 5 \alpha$-THP.

\section{$3 \alpha, 5 \alpha-T H P$ effects on picrotoxin-induced cytotoxicity}

Exposure to $1 \mathrm{mM}$ picrotoxin for $15 \mathrm{hr}$ induced a significant decrease in nerve cell survival in 6-d-old hippocampal neurons in culture (Fig. 6). Although both nerve and glial cells developed 


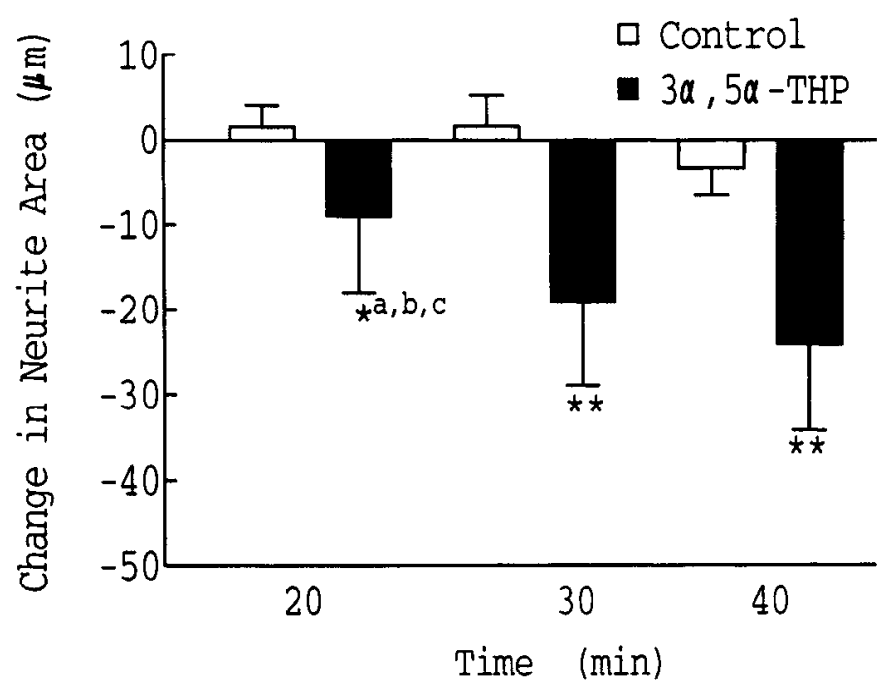

Figure 2. Influence of $3 \alpha, 5 \alpha$-THP upon neurite area. Neurite area was defined as the surface area of the projection including filopodial extensions but not including the intervening space between filopodia. Data are presented as a change from the area of the neurite assessed following a $10 \mathrm{~min}$ baseline observation period. Control ncurites underwent media exchanges identical to that of $3 \alpha, 5 \alpha$-THP-treated neurites and were observed for the same length of time. $n=18$ for control neurites; $n=$ 22 for $3 \alpha, 5 \alpha$-THP (250 nM or $1 \mu \mathrm{M}$ )-treated neurites. ${ }^{*}, p<0.05$; **, $p<0.001 ; a$, significantly different from control; $b$, significantly different from 30 min $3 \alpha, 5 \alpha$-THP exposures; $c$, significantly different from 40 $\min 3 \alpha, 5 \alpha$-THP exposure.

widespread indicators of cell death, only nerve cell death was quantified since determination of the boundaries between individual glial cells in 6-d-old control cultures was often not possible. By $15 \mathrm{hr}$ of picrotoxin exposure a significant number of ncurons staincd with trypan bluc $[F=13.43 ; \mathrm{df} 3,10 ; p<$ $0.0008]$. Nerve cell survival in $3 \alpha, 5 \alpha$-THP $(1 \mu \mathrm{M})$-treated cultures was comparable to that which occurred in control cultures. Cultures treated simultaneously with $1 \mu \mathrm{M}$ picrotoxin and $1 \mu \mathrm{M}$ $3 \alpha, 5 \alpha$-THP were protected against picrotoxin-induced nerve cell death (Fig. 6).

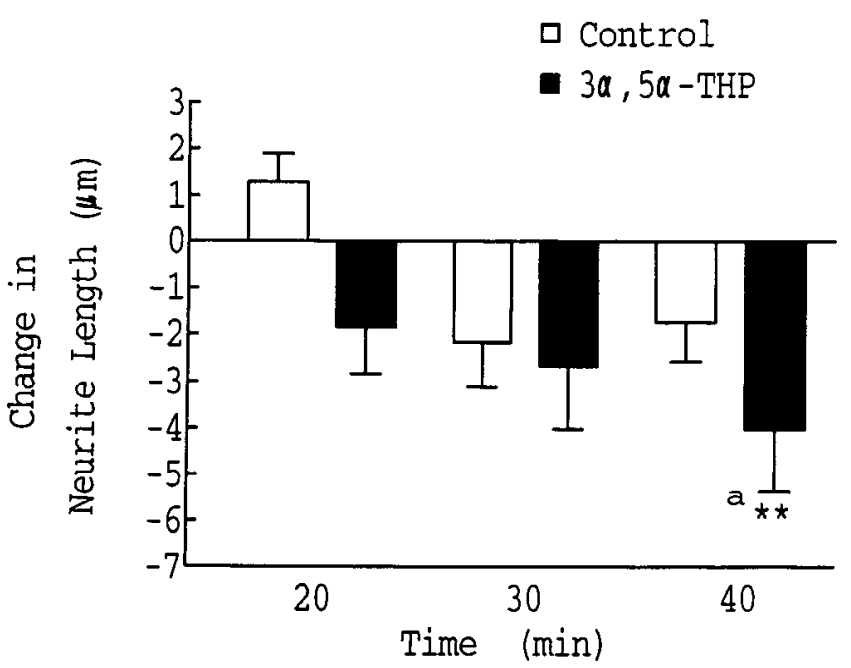

Figure 3. Influence of $3 \alpha, 5 \alpha$-THP upon neurite length. Data are presented as a change in neurite length $(\mu \mathrm{m})$ assessed following $10 \mathrm{~min}$ baseline observation period. Statistically significant differences occurred between control $(n=20)$ and $3 \alpha, 5 \alpha$-THP $(250 \mathrm{nM}$ or $1 \mu \mathrm{M})$-treated neurites $(n=20)$ at $40 \mathrm{~min}(* *, p<0.001)$ and between $20 \mathrm{~min}$ and $40 \mathrm{~min}$ exposure to $3 \alpha, 5 \alpha-\mathrm{THP}\left({ }^{a * *}, p<0.001\right)$.

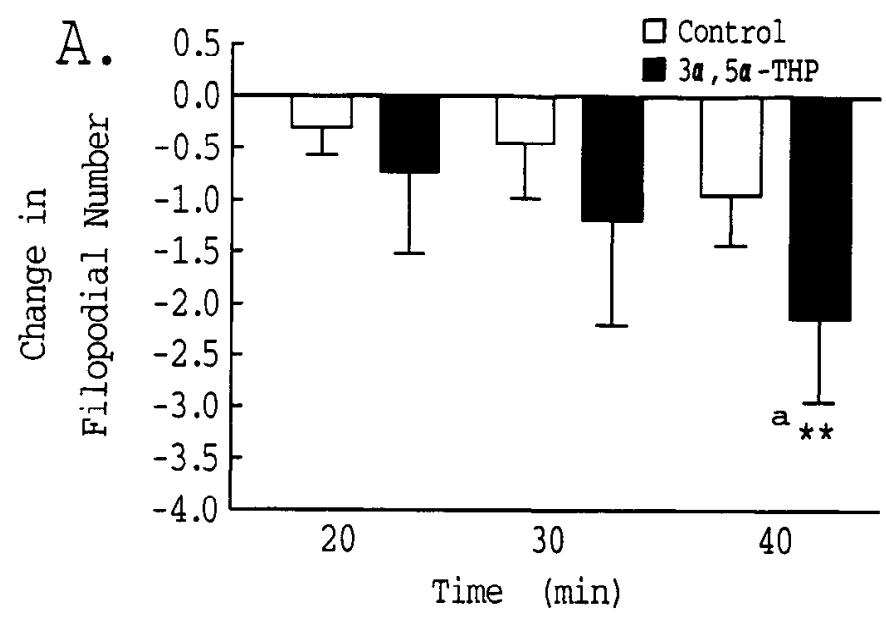

B.

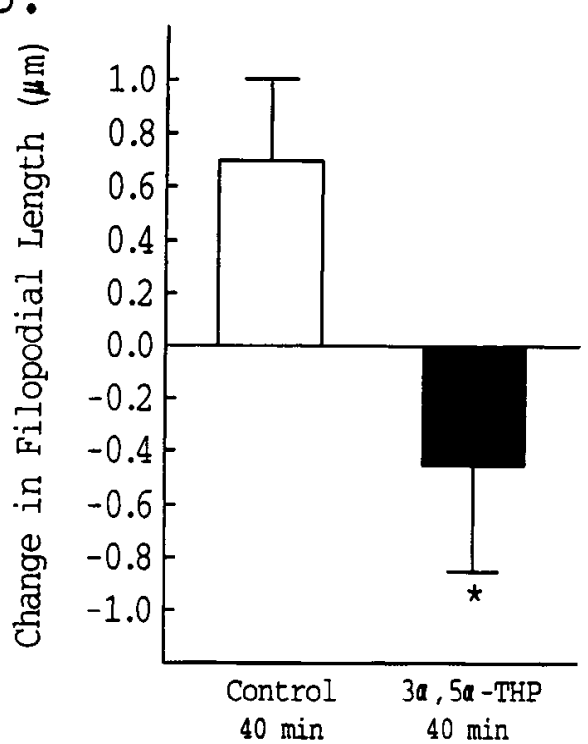

Figure 4. Influence of $3 \alpha, 5 \alpha-$ THP upon filopodial number $(A)$ and filopodial length $(B)$. Data are presented as a change in filopodial number and length assessed following the $10 \mathrm{~min}$ baseline observation period. $A$, Statistically significant differences occurred in the number of filopodia between control $(n=20)$ and $3 \alpha, 5 \alpha$-THP ( $250 \mathrm{nM}$ or $1 \mu \mathrm{M})$-treated neurites $(n=20)$ at $40 \mathrm{~min}\left({ }^{* *}, p<0.001\right)$ and between $20 \mathrm{~min}$ and 40 min exposure to $3 \alpha, 5 \alpha$-THP (a**, $p<0.02$ ). $B$, Filopodial length decreased significantly compared to matched timed control filopodia $(n$ $=144)$ following $40 \mathrm{~min} 3 \alpha, 5 \alpha$-THP exposure $(n=144 ; *, p<0.02)$.

In both the $3 \alpha, 5 \alpha$-THP-treated and the picrotoxin $/+3 \alpha, 5 \alpha$ THP-treated cultures nerve cells developed visible varicosities in their neuritic extensions (Fig. 7). Varicosity development occurred in neurons with and without structural contacts with other cells and also occurred in glial cells.

\section{Reversal of $3 \alpha, 5 \alpha-T H P$-induced flopodial regression by 17} $\beta$-estradiol

Every neurite $(n=22)$ that was treated with $3 \alpha, 5 \alpha$-THP for 40 min was subsequently treated with $1 \mu_{\mathrm{M}} 17 \beta$-estradiol. Of those 22 neurites, five neurites showed an extremely rapid induction of filopodial growth within seconds of $17 \beta$-estradiol exposure (Fig. 8). A comparison of the change in filopodial number that occurred during the $10 \mathrm{~min}$ baseline observation period, the change in filopodial number that occurred during the $40 \mathrm{~min}$ $3 \alpha, 5 \alpha$-THP exposure, and the change in filopodial number that 


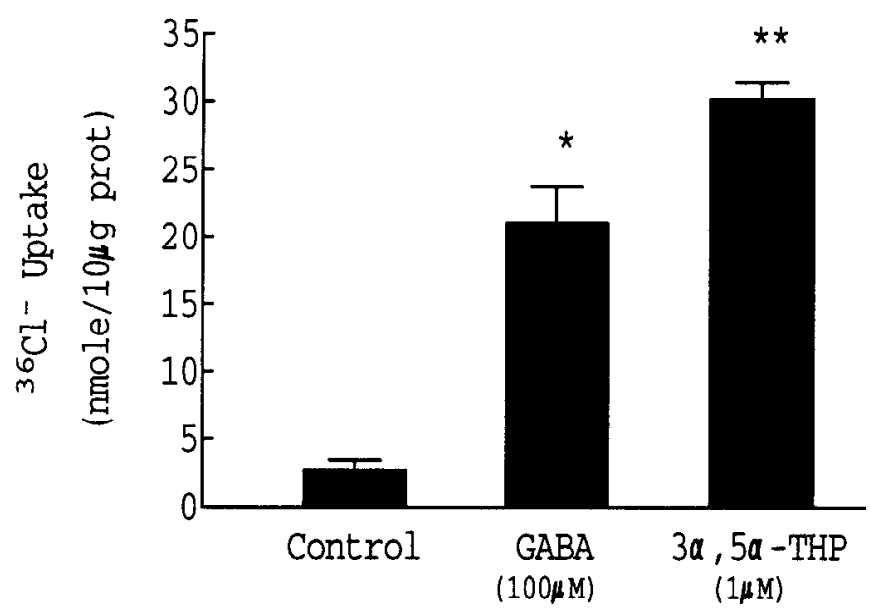

Figure 5. Effect of $3 \alpha, 5 \alpha$-THP on uptake of ${ }^{36} \mathrm{Cl}^{-}$by hippocampal nerve cell cultures. Three-day-old hippocampal nerve cell cultures were exposed to $100 \mu \mathrm{M}$ GABA or $1 \mu \mathrm{M} 3 \alpha, 5 \alpha$-THP in the presence of ${ }^{36} \mathrm{Cl}^{-}$ $(9.6 \mu \mathrm{Ci} / \mathrm{ml})$ for $10 \mathrm{sec} .{ }^{36} \mathrm{Cl}^{-}$uptake was measured as described in Materials and Methods. Data are from one experiment and are representative of three separate experiments. Values represent mean \pm SEM, $n=3$ cultures/per condition $\left({ }^{*}, p<0.05 ;{ }^{* *}, p<0.01\right.$; significantly different from basal uptake).

occurred during a $90 \mathrm{sec}$ exposure to $17 \beta$-estradiol is shown in Figure 9.

A similar spontaneous response was never observed in control neurons that were observed for an equal amount of time, under the same constant illumination as those treated with steroids and that received the same number and temporal sequence of media exchanges $(n=20)$. Similarly, progesterone $(1 \mu \mathrm{M})$ pretreatment for $40 \mathrm{~min}$ followed by exposure to $1 \mu \mathrm{M} 17 \beta$-estradiol also did not induce a spontaneous outgrowth of filopodia $(n=$ 18 ). Lastly, the reverse condition in which neurites were pretreated with $17 \beta$-estradiol followed by $3 \alpha, 5 \alpha$-THP exposure also did not result in spontaneous filopodial outgrowth $(n=5)$.

\section{Discussion}

The undulating process of cytoarchitectural emergence and retraction constitutes a normal growth pattern during nerve cell development (Aletta and Greene, 1988; Smith, 1988). Under normal conditions, the retraction/emergence process can occur within minutes for filopodia and hours or days for changes in neurite length and area to become apparent. In this study, control neurites exhibited very little variability in growth during the $60 \mathrm{~min}$ of observation. In marked contrast, in $3 \alpha, 5 \alpha$-THPtreated neurons, a decrement was observed in each morphological parameter within 20 min that reached significance by 40 $\mathrm{min}$. Because of the rapidity of the $3 \alpha, 5 \alpha$-THP-induced regression, because no significant change was observed in control neurites, and because the level of significance at $40 \mathrm{~min}$ ranged from $p<0.02$ to $p<0.0001$, it is highly unlikely that the regression of neuronal morphology is due to chance alone or to factors associated with the observation paradigm.

The concentration of $3 \alpha, 5 \alpha-\mathrm{THP}$ required to induce morphological retraction ( $250 \mathrm{~nm}$ to $1 \mu \mathrm{M}$ ) clearly exceeds plasma levels. Indeed, these concentrations are greater than the highest levels obtained during pregnancy $(\sim 100 \mathrm{~nm})$. One can invoke the usual pharmacological explanation to such a situation by relying on the fact that local synaptic concentrations of any substance can greatly exceed the levels found in volumes of measure such as milligrams of protcin or millilitcrs of plasma. Whether this situation is in fact the case remains to be deter-

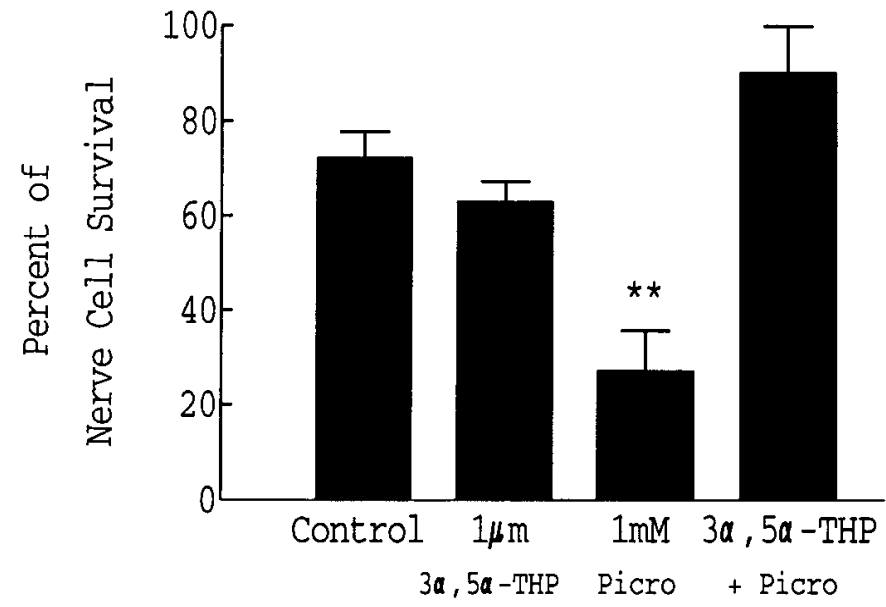

Figure 6. $3 \alpha, 5 \alpha$-THP protection against picrotoxin-induced nerve cell death. The number of trypan blue dye-excluding cells $/ 100$ morphologically identified neurons was determined (mean + SEM, $n=5$ cultures per condition) after $15 \mathrm{hr}$ of exposure to $1 \mathrm{~mm}$ picrotoxin (Picro), $1 \mu \mathrm{M}$ $3 \alpha, 5 \alpha$-THP or $1 \mathrm{~mm}$ picrotoxin $+1 \mu \mathrm{M} 3 \alpha, 5 \alpha$-THP. Control cells received no treatment. Data are presented as percentage of surviving nerve cells. All cultures were $6 \mathrm{~d}$ of age and contained both neurons and glial cells $(* *, p<0.01$, significantly different from all other conditions).

mined. The requirement for supraphysiological levels of $3 \alpha, 5 \alpha-$ THP is probably related to the presence of steroid-binding proteins such as albumin present in the serum, where it is well documented that only about $2 \%$ of sex steroids exist in a free, pharmacologically active form, with the remainder being bound to sex hormone binding globulin and albumin. The presence of these steroid-binding proteins in the serum in all likelihood significantly reduced the total amount of free steroid. Moreover, the minimally effective concentration of $250 \mathrm{nM} 3 \alpha, 5 \alpha$-THP is only 1.5 -fold higher than the levels found in plasma during pregnancy $(\sim 100 \mathrm{~nm})$. The possibility that the regressive effects of $3 \alpha, 5 \alpha$-THP are mediated merely by perturbations in membrane fluidity is unlikely, since neither $1 \mu \mathrm{M} 3 \beta, 5 \beta$-THP nor 17 $\beta$-estradiol induced retraction and $30 \%$ of the cells treated with $3 \alpha, 5 \alpha$-THP showed no filopodial or neuritic regression. Moreover, no steroid studied in a previously published report (Brinton, 1993) induced regression at the same concentration.

In addition to the retraction of neuronal morphology, $3 \alpha, 5 \alpha-$ THP-treated neurites displayed retrograde movement of PDBs that populated the cytoplasmic domain of neuronal extensions. Prolonged treatment with $3 \alpha, 5 \alpha$-THP induced the development of varicosities in both nerve and glial cell extensions. The composition of such PDBs and varicosities was explored by Koenig et al. (1985). These investigators found that PDBs and varicosities contained $\alpha$-spectrin, actin, and calmodulin in addition to cytomembranes. They also found that the predominant structure of the varicosities was a large aggregation of anastomosing tubular, smooth endoplasmic reticulum embedded in an amorphous matrix. The rapid formation of PDBs and the associated retrograde transport of cytomembranes, structural proteins, growth-associated enzymes and smooth endoplasmic reticulum following $3 \alpha, 5 \alpha$-THP exposure are consistent with regression of neuritic structure.

Thus, the data presented here document four main findings. (1) $3 \alpha, 5 \alpha$-THP can, in responsive cells, induce significant retraction of neuronal morphology within minutes following exposure. Moreover, the morphological regression induced by $3 \alpha, 5 \alpha-$ THP is mirrored in the retrograde movement of neuritic organelles. In addition, the response of retraction induced by 

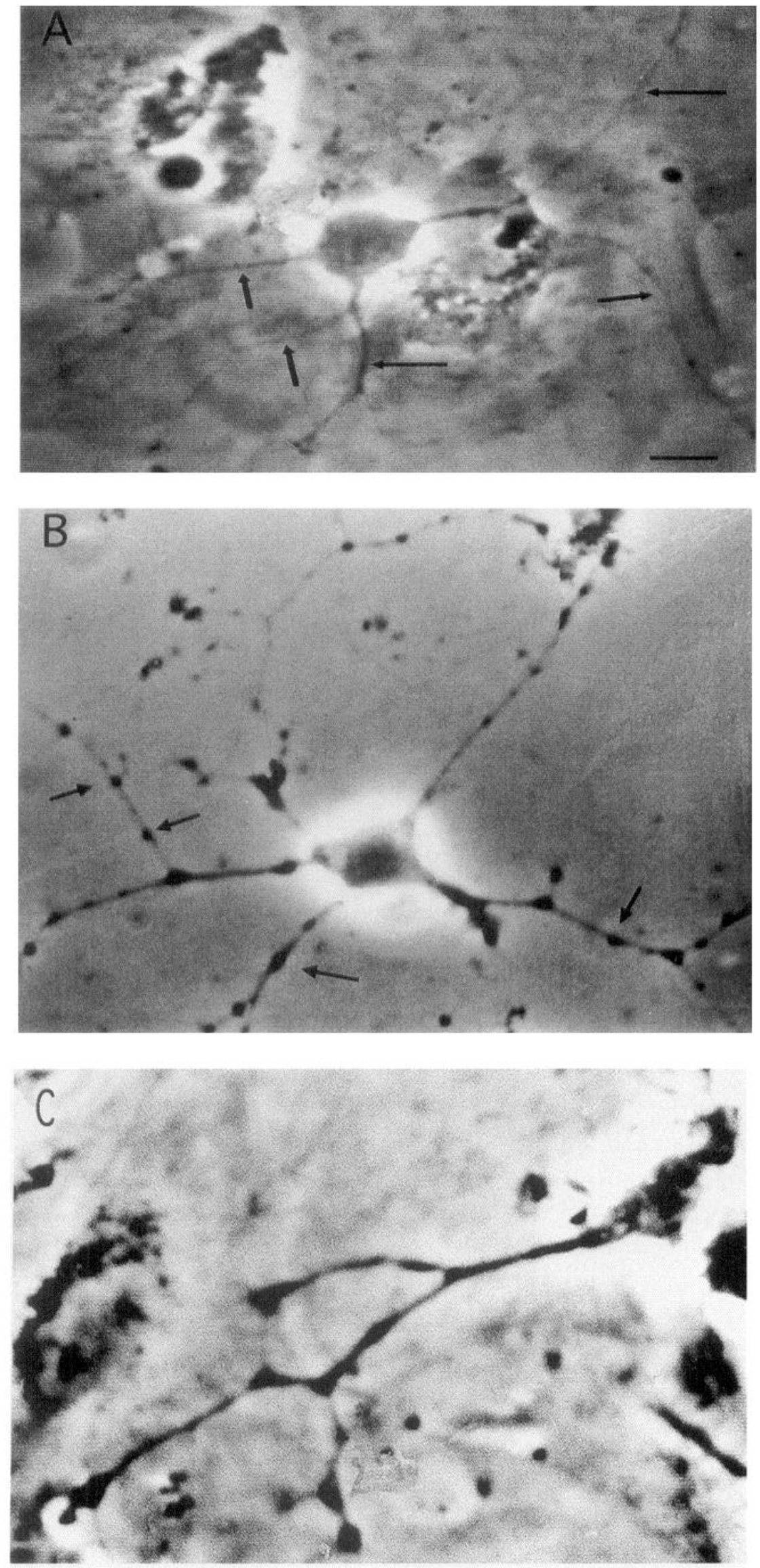

Figure 7. Development of varicosities and maintenance of structural contact in 6-d-old hippocampal neurons treated for $15 \mathrm{hr}$ with $1 \mu \mathrm{M} 3 \alpha, 5 \alpha$-THP. $A$, Photomicrograph of a 6 -d-old control hippocampal neuron. Arrows point to neuritic extensions that are free of varicosities. $B$, Hippocampal neuron treated with $1 \mu \mathrm{M} 3 \alpha, 5 \alpha$-THP for $15 \mathrm{hr}$. Arrows point to a few of the many varicosities that developed over the $15 \mathrm{hr}$ of exposure to $3 \alpha, 5 \alpha$-THP. C, Hippocampal nerve cell treated with $1 \mu \mathrm{M}$ $3 \alpha, 5 \alpha$-THP for $15 \mathrm{hr}$ that developed varicosities but that remained attached to underlying glial cells. Note that cells treated with $3 \alpha, 5 \alpha$-THP ( $B$ and $C$ ) contain pronounced varicosities in cellular extensions, whereas the control cell docs not show evidence of varicosity development. Scale bar, $25 \mu \mathrm{m}$. 

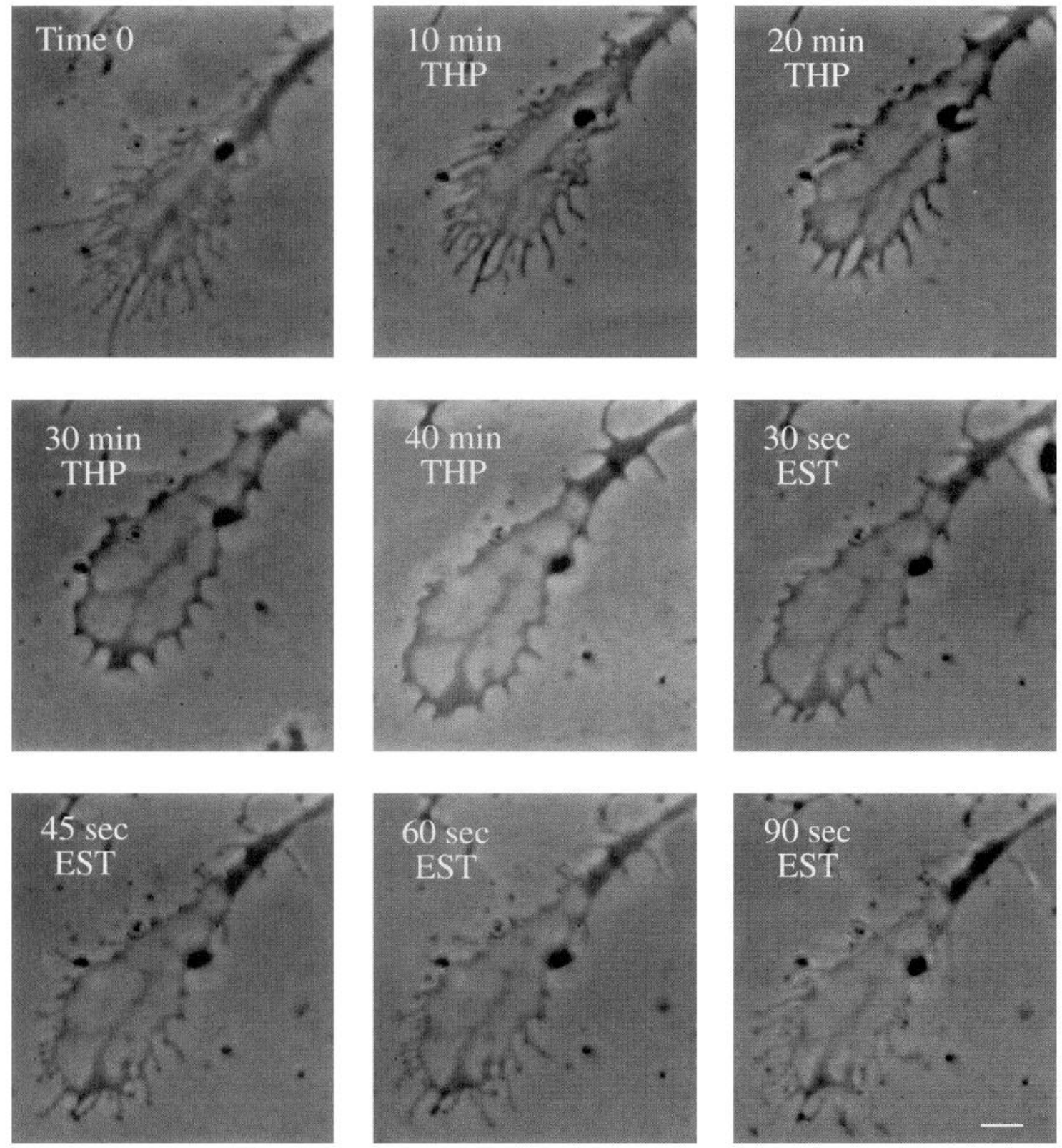

Figure 8. Photomicrograph of a hippocampal nerve cell growth cone prior to time 0 ) and during $10,20,30$, and 40 min of exposure to $1 \mu \mathrm{M}$ $3 \alpha, 5 \alpha$-THP (THP) followed by $30,45,60,90 \mathrm{sec}$ of exposure to $1 \mu \mathrm{M} 17 \beta$-estradiol (EST). The relative time of recording (in min or sec) of the same growth cone is denoted in the upper left corner of each panel. Note the regression of filopodia during THP exposure and the reemergence of filopodial during EST exposure. Scale bar, $5 \mu \mathrm{m}$.

$3 \alpha, 5 \alpha$-THP appears to be regulated by the formation of structural contact with other cells such that structural contact renders the neurite unresponsive to the regressive effects of $3 \alpha, 5 \alpha$-THP but not to the development of varicosities. (2) Chloride influx could be partly involved in the process of cytoarchitectural retraction since $3 \alpha, 5 \alpha$-THP induced a significant influx of chloride within $10 \mathrm{sec}$ of exposure. (3) $3 \alpha, 5 \alpha$-THP can protect neurons against picrotoxin-induced cytotoxicity. (4) The $3 \alpha, 5 \alpha$-THPinduced regression of filopodia can, in select instances, be reversed by subsequent exposure to $17 \beta$-estradiol.

\section{Potential intracellular mechanism regulating $3 \alpha, 5 \alpha-T H P-$} induced neurite and filopodial regression

The $40 \mathrm{~min}$ time frame for morphological retraction to reach significance could involve a genomic mechanism of action, sim- ilar to the mechanism of action for many steroids. However, we have demonstrated in an earlier study that $3 \alpha, 5 \alpha$-THP does not bind to progesterone nuclear receptors (Gee et al., 1988). In addition, we and others have also demonstrated that the $3 \alpha, 5 \alpha$-THP binding site is a unique regulatory site on the GABAchloride channel complex (Gee et al., 1987, 1988; Morrow et al., 1987, 1990). Morrow and her colleagues $(1987,1990)$ have extensively characterized $3 \alpha, 5 \alpha$-THP-induced chloride uptake in cortical synaptosomes and have shown significant potentiating effects within $5 \mathrm{sec}$ of exposure to the steroid.

Several laboratories investigated the underlying mechanism of $3 \alpha, 5 \alpha$-THP-induced chloride uptake using single-channel analysis. Lambert et al. (1987) found prolongation of the burst duration of GABA-chloride channels following exposure to 1 $\mu \mathrm{M} 3 \alpha, 5 \alpha$-THP. Harrison and Simmonds (1984) demonstrated 
that progesterone steroid metabolite regulation of chloride channels is specific to the GABA-chloride channel complex since no effect upon glycine-mediated transmission was observed. These investigators also found that a $2 \mathrm{~min}$ exposure to alphaxalone (3 $\alpha$-hydroxy-5 $\alpha$-pregnane 11,20-dione, a steroid very similar to $3 \alpha, 5 \alpha$-THP) enhanced GABA-mediated transmission for $3 \mathrm{hr}$. This finding demonstrates that long-lasting effects upon chloride channel activity can be achieved with short exposures to high concentrations of progesterone steroid metabolites. Such a phenomenon may be operating in the case of $3 \alpha, 5 \alpha$-THP-induced ${ }^{36} \mathrm{Cl}^{-}$uptake. However, because $40 \mathrm{~min}$ of exposure to $3 \alpha, 5 \alpha-$ THP did not result in an increase in ${ }^{36} \mathrm{Cl}^{-}$uptake above basal levels, it is not clear whether the initial influx of chloride induced by $3 \alpha, 5 \alpha$-THP within $10 \mathrm{sec}$ of exposure is related to the neurite regression or is an initial signal that activates a secondary mechanism that ultimately mediates neurite regression. The fact that chloride influx was not different than basal at $40 \mathrm{~min}$ does indicate, however, that the cytoarchitectural retraction induced by $3 \alpha, 5 \alpha-$ THP is not a result of intracellular changes in osmolarity or an inability to maintain chloride ion balance.

It is becoming increasingly clear that different cell types and different stages of development are associated with different subunit composition of the chloride channel complex (Schofield et al., 1987; Levitan et al., 1988; Montpied et al., 1989; Puia et al., 1990; Lan et al., 1991; MacLennan et al., 1991; McKernan et al., 1991; Paul and Purdy, 1992). Supporting the developmental changes in $\mathrm{GABA}_{\mathrm{A}}$ receptor subunit composition, Barker and colleagues (Maric et al., 1992) have shown that cortical cells exhibit unique electrophysiological responses to GABA and neurosteroids that change within the course of a few days (E13E19) during embryogenesis. Thus, it appears reasonable to suggest that developmental and cell-specific factors operate to mediate the responsivity to neurosteroid exposure. Indeed, such developmental regulated responsivity was evident in cultured neurons utilized in the present study. Neurites that had not made structural contact exhibited regression potential, whereas those that had made contact did not.

\section{Comparison between the effects of $3 \alpha, 5 \alpha-T H P$ and 17 $\beta$-estradiol}

As the data presented in this study indicate, $17 \beta$-estradiol can reverse the regression induced by $3 \alpha, 5 \alpha$-THP. In a previous report, $17 \beta$-estradiol was found to induce filopodial growth within 5-10 min of exposure at concentrations identical to the ones used in this study (Brinton, 1993). $17 \beta$-Estradiol-induced outgrowth was specific in that neither $17 \alpha$-estradiol, testosterone, progesterone, or corticosterone promoted outgrowth. $3 \alpha, 5 \alpha-$ THP pretreatment markedly reduced the time course for 17 $\beta$-estradiol activation of filopodial growth exposure from minutes to seconds. The cellular selectivity for $17 \beta$-estradiol reversal of $3 \alpha, 5 \alpha$-THP-induced filopodial regression is consistent with previous findings regarding $17 \beta$-estradiol effects upon filopodial growth (reviewed in Brinton, 1993), regulation of dendritic spine growth (Gould ct al., 1990), and the electrophysiological effects (Teyler et al., 1980; Foy et al., 1982; Nabekura et al., 1986; Minami et al., 1990; Wong and Moss, 1991).

The highly selective effect of $17 \beta$-estradiol on filopodial outgrowth is not unique. Based on the studies of neurotrophic factors and neurotransmitters in both the PNS and CNS, it appears that ensembles of neurons exhibit unique and highly specific patterns of neurotrophic factor responsivity. This characteristic holds true for neurotransmitter systems that act as
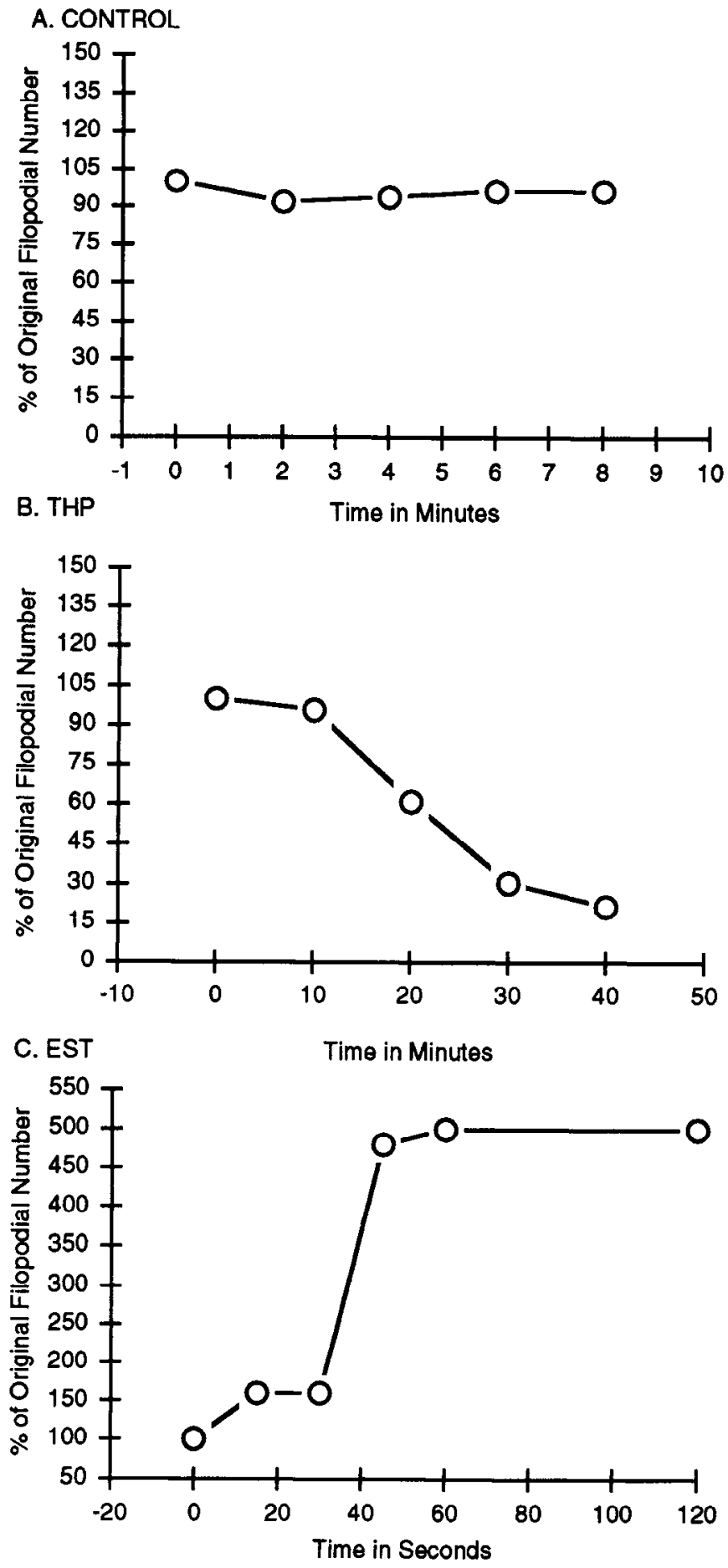

Figure 9. Comparative analysis of change in filopodial number following exposure to $1 \mu \mathrm{M} 3 \alpha, 5 \alpha$-THP (THP) and $1 \mu \mathrm{m} 17 \beta$-estradiol $(E S T)$. Data are quantitative analysis of growth cone shown in Figure 8. A similar temporal pattern of THP-induced regression followed by reemergence of filopodia within seconds was observed in other estrogen responsive cells. $A$ depicts change in filopodial number that occurred during baseline observation. Note that the percentage of original number of filopodia remains constant around $100 \%$, indicating that very little change occurred during the baseline period. $B$ depicts change in filopodial number that occurred during exposure to $1 \mu \mathrm{M} 3 \alpha, 5 \alpha$-THP (THP). $C$ depicts change in filopodial number that occurred during exposure to $1 \mu \mathrm{m} 17 \beta$-estradiol $(E S T)$. Note that in control and THP panels $(A$, $B$ ) time is recorded in minutes, while in EST panel $(C)$ time is recorded in seconds. 
neurotrophic agents (Berg, 1984; Brinton and Gruener, 1987; Mattson, 1988; Lipton and Kater, 1989; Brinton, 1990) and for growth factors such as NGF, significantly and selectively influence ncuritc outgrowth and survival (rcviewed in Berg, 1984; Levi-Montalcini, 1987; Barde, 1989).

The exact mechanism for the rapid effect of $17 \beta$-estradiol hippocampal nerve cell outgrowth has yet to be identified; however, regulation of channel function appears a likely candidate. Indeed, Nabekura et al. (1986) found that $17 \beta$-estradiol increased potassium conductance in medial amygdala neurons. Numerous other studies have documented that $17 \beta$-estradiol has potent and rapid excitatory effects upon nerve cells in the hippocampus (Teyler et al., 1980; Foy et al., 1982; Wong and Moss, 1991) as well as in other brain regions (Nabekura et al., 1986; Minami et al., 1990).

\section{Functional and basic science implications of $3 \alpha, 5 \alpha-T H P-$ induced morphological regression}

The conversion of progesterone to progesterone metabolite steroids by hypothalamic tissue (Karavolas and Hodges, 1990, 1991), the synthesis of $3 \alpha, 5 \alpha$-THP and other progesterone metabolites by cultured fetal glial cells (Jung-Testas et al., 1989), the localization of the steroid-converting enzyme $3 \alpha$-hydroxysteroid oxidoreductase torglia in brain (Krieger and Scott, 1989), and the documentation that $3 \alpha$-hydroxysteroid oxidoreductase is present in fetal brain, that fetal brain is one of the first tissues to produce $3 \alpha, 5 \alpha$-THP (Ward et al., 1992), and the formation of the $3 \alpha, 5 \alpha$-THP by the fetal-placental unit, all suggest that steroid metabolites can play an important role in neural development. Indeed, plasma levels can reach $30 \mathrm{ng} / \mathrm{ml}(\sim 100 \mathrm{nM})$ during the third trimester of pregnancy and remain elevated for months (Paul and Purdy, 1992). Moreover, it was demonstrated by Holzbauer et al. (1985) that, in addition to synthesis in the brain, both the ovary and the adrenal gland synthesize $3 \alpha, 5 \alpha$-THP. These investigators also showed that levels of $3 \alpha, 5 \alpha-$ THP increased dramatically following chronic osmotic challenge. Thus, there are an ample number of sites and physiologically relevant circumstances for $3 \alpha, 5 \alpha$-THP synthesis both during development and throughout the life-span of the animal to postulate reasonably that $3 \alpha, 5 \alpha$-THP may indeed play an important role in neural development and in sculpting neuronal architecture throughout the life of the animal.

In addition to potentially being involved in normal physiological processes, supraphysiologic concentrations of $3 \alpha, 5 \alpha$-THP are conceivably relevant to the potential therapeutic application of this progesterone metabolite. In behavioral studies of both antianxiety (Wieland et al., 1991) and antiepileptic properties of $3 \alpha, 5 \alpha-\mathrm{THP}$, injections of $20-100 \mathrm{mg} / \mathrm{kg}$ are not uncommon (Belelli et al., 1989). Clearly, administration of $3 \alpha, 5 \alpha$-THP to women during the follicular phase of the menstrual cycle or to pregnant women will raise already high existing levels of $3 \alpha, 5 \alpha-$ THP. Results of this study suggest that high levels of $3 \alpha, 5 \alpha-$ THP could potentially effect fetal nerve cell growth.

From a clinical perspective, one must question whether the therapeutic doses of $3 \alpha, 5 \alpha$-THP necessary to protect against seizure activity will influence normally occurring growth such as that which may occur with learning and memory (Brinton and Gruener, 1987; Brinton, 1990; reviewed in Brinton, 1993). While addressing that question, it is important to note that $3 \alpha, 5 \alpha$-THP did not erode structural connections even when those connections were newly formed. In addition, the combination of $3 \alpha, 5 \alpha-$ THP and picrotoxin produced a nerve cell sur- vival rate that was comparable to that of control cultures and even showed a modest enhancement of survival rate. While the complexity of neuronal morphology under these conditions remains to be detcrmined, structural contacts between neurons and glial cells were still clearly apparent following $15 \mathrm{hr}$ of exposure to $1 \mu \mathrm{M} 3 \alpha, 5 \alpha$-THP. These data would suggest that existing neural circuits are not susceptible to $3 \alpha, 5 \alpha$-THP-induced retraction. Thus, it is not unreasonable to speculate that a therapeutic regimen of $3 \alpha, 5 \alpha$-THP, which would tightly titrate inhibition of excessive nerve cell excitation but which would preserve appropriate nerve cell excitability, could result in normal nerve cell growth under desirable circumstances such as during learning and memory.

From a basic science perspective, the ability of a progesterone steroid metabolite, $3 \alpha, 5 \alpha$-THP, to induce significant morphological changes within minutes of exposure has fundamental implications for conceptualization of both the time requirements for steroid-induced cytoarchitectural modifications as well as the role of steroid metabolites in sculpting neuronal circuitry. Temporally, the present data suggest that steroids and steroid metabolites can induce modifications of neuronal architecture in substantially less time then that required for morphological changes resulting from nuclear receptor activation of genomically mediated events. Collectively, the present data suggest that steroid metabolites can have a profound influence on neuronal morphology. Such cytoarchitectural modifications could have significant implications for the development and function of neural circuitry.

\section{References}

Aletta JM, Greene LA (1988) Growth cone configuration and advance: a time-lapse study using video-enhanced differential interference contrast microscony. J Neurosci 8:1425-1435.

Arnold A, Breedlove S (1985) Organizational and activational effects of sex steroids on brain and behavior: a reanalysis. Horm Behav 19: $469-498$.

Arnold AP, Gorski RA (1984) Gonadal steroid induction of structural sex differences in the CNS. Annu Rev Neurosci 7:413-442.

Backstrom T, Bixo M, Hammarback S (1985) Ovarian steroid hormones: effects on mood, behaviour and brain excitability. Acta Obstet Gynecol Scand [Suppl] 130:19-24.

Barde YA (1989) Trophic factor and neuronal survival. Neuron 2:15251534.

Barker JL, Harrison NL, Lange GD, Majewska MD, Owen DG (1986) Voltage-clamp studies of the potentiation of GABA-activated chloride conductance by alphaxalone and a reduced metabolite of progesterone. J Physiol (I ond) 377:83P.

Bartlett W, Banker G (1984) An electron microscopic study of the development of axons and dendrites by hippocampal neurons in cultures. II. Synaptic relationships. J Neurosci 4:1964-1965.

Baulieu EE (1991) Neurosteroids: a function in the brain. In: FIDIA Research Foundation symposium series, Vol 8, Neurosteroids and brain function (Costa E, Paul SM, eds), pp 135-146. New York: Thieme.

Baulieu EE, Robel P (1990) Neurosteroids: a new brain function? J Steroid Biochem 37:395-403.

Belelli D, Bolger MB, Gee KW (1989) Anticonvulsant profile of the

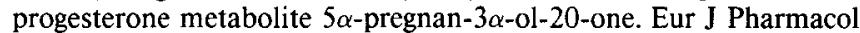
166:L325-L329.

Ben-Ari Y, Represa A (1990) Brief seizure episodes induce long-term potentiation and mossy fibre sprouting in the hippocampus. Trends Neurosci 13:312-318.

Berg DK (1984) New neuronal growth factors. Annu Rev Neurosci 7:149-170.

Berthois Y, Katzenellenbogen JA, Katzenellenbogen BS (1986) Phenol red in tissue culture media is a weak estrogen: implications concerning the study of estrogen responsive cells in culture. Proc Natl Acad Sci USA 83:2496-2500.

Black JE, Greenough WT (1991) Developmental approaches to the 
memory process. In: Learning and memory: a biological view (Martinez JL, Kesner RP, eds), pp 61-92. San Diego: Academic.

Brinton RD (1993) $17 \beta$-Estradiol induction of filopodial growth in cultured hippocampal neurons within minutes of exposure. Mol Cell Neurosci 4:36-46.

Brinton RE (1990) Vasopressin promotes hippocampal nerve cell growth in culture. Soc Neurosci Abstr 16:822.

Brinton RE, Gruener R (1987) Vasopressin promotes neurite growth in cultured embryonic neurons. Synapse 1:329-334.

Cronin J, Dudek FE (1988) Chronic seizures and collateral sprouting of dentate mossy fibers after kainic acid treatment in rats. Brain Res 474:181-184

Cronin J, Obenaus A, Houser CR, Dudek FE (1992) Electrophysiology of dentate granule cells after kainate-induced synaptic reorganization of the mossy fibers. Brain Res 573:305-310.

Desmond NL, Levy WB (1983) Synaptic correlates of associative potentiation/depression: an ultrastructural study in the hippocampus. Brain Res 265:21-30.

Foy MR, Teyler TJ, Vardaris RM (1982) THC and $17 \beta$-estradiol in hippocampus. Brain Res Bull 8:341-345.

Gee KW (1988) Steroid modulation of the GABA/benzodiazepine receptor-linked chloride ionophore. Mol Neurobiol 2:291-317.

Gee KW, Chang WC, Brinton RE, McEwen BS (1987) GABA-dependent modulation of the $\mathrm{Cl}$ ionophore by steroids in rat brain. Eur $\mathrm{J}$ Pharmacol 136:419-423.

Gee KW, Bolger MB, Brinton RE, Corini H, McEwen BS (1988) Steroid modulation of the chloride ionophore in rat brain: structureactivity requirements, regional dependence and mechanism of action. J Pharmacol Exp Ther 246:803-812.

Geinisman Y, Morrell F, DeToledo-Morrell L (1988) Remodeling of synaptic architecture during hippocampal "kindling." Proc Natl Acad Sci USA 85:3260-3264.

Gould E, Woolley CS, Frankfurt M, McEwen BS (1990) Gonadal steroids regulate dendritic spine density in hippocampal pyramidal cells in adulthood. J Neurosci 10:1286-1291.

Greenough WT, Bailey C (1988) The anatomy of a memory: convergence of results across a diversity of tests. Trends Neurosci 11:142147.

Hansen GH, Meir E, Abraham J, Schousboe A (1987) Trophic effects of GABA on cerebellar granule cells in culture. In: Neurtrophic activity of GABA during development (Redburn DA, Schousboe A, eds), pp 139-159. New York: Liss.

Harrison NL, Simmonds MA (1984) Modulation of the GABA receptor complex by a steroid anesthetic. Brain Res 323:287-292.

Harrison NL, Majewska MD, Harrington JW, Barker JW (1987) Structure-activity relationships for steroid interaction with the $\gamma$-amino-

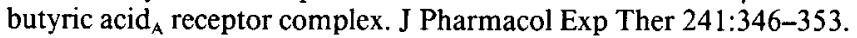

Holzbauer M, Birmingham MK, DeNicola AF, Oliver JT (1985) In vivo secretion of $3 \alpha$-hydroxy-5 $\alpha$-pregnan-20-one, a potent anaesthetic steroid, by the adrenal gland of the rat. J Steroid Biochem 22:97102.

Hu ZY, Bourreau E, Jung-Testas, I Robel P, Baulieu EE (1987) Neurosteroids: oligodendrocyte mitochondria convert cholesterol to pregnenolone. Proc Natl Acad Sci USA 84:8215-8219.

Jung-Testas I, Hu ZY, Baulieu EE, Robel P (1989a) Steroid synthesis in rat brain cultures. J Steroid Biochem 34:511-519.

Jung-Testas I, Hu ZY, Baulieu EE, Robel P (1989b) Neurosteroids: biosynthesis of pregnenolone and progesterone in primary cultures of rat glial cells. Endocrinology 125:2083-2091.

Karavolas HJ, Hodges DR (1990) Neuroendocrine metabolism of progesterone and related progestins. CIBA Found Symp 153:22-55.

Karavolas HJ, Hodges DR (1991) Metabolism of progesterone and related steroids by neural and neuroendocrine structures. In: FIDIA Research Foundation symposium series, Vol 8, Neurosteroids and brain function (Costa E, Paul SM, eds), pp 135-146. New York Thieme.

Koenig E, Kinsman S, Repasky E, Sultz L (1985) Rapid mobility of motile varicosities and inclusions containing $\alpha$-spectrin, actin, and calmodulin in regenerating axons in vitro. J Neurosci 5:715-729.

Krieger NR, Scott RG (1989) Nonneuronal localization for steroid converting enzyme: $3 \alpha$-hydroxysteroid oxidoreductase in olfactory tubercle of rat brain. J Neurochem 52:1866-1870.

Lambert JJ, Peters JA, Cottrell GA (1987) Actions of synthetic and endogenous steroids on the GABA receptor. Trends Pharmacol Sci 8:224-227.

Lambert JJ, Peters JA, Sturgess NC, Hales TG (1991) Steroid mod- ulation of the GABA receptor complex: electrophysiological studies. CIBA Found Symp 153:56-82.

Lan NC, Gee KW, Bolger MB, Chen JS (1991) Differential responses of expressed recombinant human $\gamma$-aminobutyric acid a receptors to neurosteroids. J Neurochem 57:1818-1821.

Le Goascogne C, Robel P, Gouezou M, Sananes N, Baulieu EE, Waterman $M$ (1987) Neurosteroids: cytochrome $P 450_{\text {scc }}$ in rat brain. Science 237:1212-1215.

Levi-Montalcini R (1987) The nerve growth factor 35 years later. Science 237:1154-1162.

Levitan ES, Shofield PR, Burt DR, Rhee LM, Wisden W, Kohler M, Fujita N, Rodriguez HF, Stephenson A, Darlison MG, Barnard EA, Seeburg PH (1988) Structural and functional basis for GABA receptor heterogeneity. Nature 335:76-79.

Lipton SA, Kater SB (1989) Neurotransmitter regulation of neuronal outgrowth, plasticity and survival. Trends Neurosci 12:265-270.

MacLennan AJ, Brecha N, Khrestchatisky M, Sternini C, Tillakaratne NJ, Chiang MY, Anderson K, Lai M, Tobin AJ (1991) Independent cellular and ontogenetic expression of mRNAs encoding three alpha polypeptides of the rat GABA A receptor. Neuroscience 43:369-380.

Madtes P (1987) Ontogeny of the GABA receptor complex. In: Neurotrophic activity of GABA during development (Redburn DA, Schousboe A, eds), pp 161-187. New York: Liss.

Majewska MD, Harrison NL, Schwartz RD, Barker JL, Paul SM (1986) Steroid hormone metabolites are barbiturate-like modulators of the GABA receptor. Science 323:1004-1007.

Maric D, Maric J, Smith SV, Barker JL (1992) Development of membrane excitability in the rat cortex begins at embryonic day 11 . Soc Neurosci Abstr 18:24.2.

Mattson MP (1988) Neurotransmitters in the regulation of neuronal cytoarchitecture. Brain Res Rev 13:179-212.

Mattson MP, Taylor-Hunter A, Kater SB (1988) Neurite outgrowth in individual neurons of a neuronal population is differentially regulated by calcium and cyclic AMP. J Neurosci 8:1704-1711.

McEwen BS (1991) Our changing ideas about steroid effects on an ever-changing brain. Semin Neurosci 3:497-507.

McEwen BS (1992) Non-genomic and genomic effects of steroids on neural activity. Trends Pharmacol Sci 12:141-147.

McEwen BS, Brinton RE (1987) Neuroendocrine aspects of adaptation. Prog Brain Res 72:11-26.

McKernan RM, Cox P, Gillard NP, Whiting P (1991) Differential expression of $\mathrm{GABA}_{\mathrm{A}}$ receptor alpha subunits in rat brain during development. FEBS Lett 286:44-46.

Minami T, Oomura Y, Nabekura J, Fukuda A (1990) $17 \beta$-Estradiol depolarization of hypothalamic neurons is mediated by cyclic AMP. Brain Res 519:301-307.

Montpied P, Ginns El, Martin BM, Stetler D, O'Carroll AM, Lolait SJ, Mahan LC, Paul SM (1989) Multiple GABA receptor alpha subunit mRNAs revealed by developmental and regional expression in rat, chicken and human brain. FEBS Lett 258:94-98.

Morrow AL, Suzdak PD, Paul SM (1987) Steroid hormone metabolites potentiate GABA receptor-mediated chloride flux with nanomolar potency. Eur J Pharmacol 142:483-485.

Morrow AL, Pace JR, Purdy RH, Paul SM (1990) Characterization of steroid interactions with $\gamma$-aminobutyric acid receptor-gated chloride ion channels: evidence for multiple steroid recognition sites. Mol Pharmacol 37:263-270.

Nabekura J, Oomura Y, Minami T, Mizuno Y, Fukuda A (1986) Mechanism of the rapid effect of $17 \beta$-estradiol on medial amygdala neurons. Science 233:226-228.

Paul SM, Purdy RH (1992) Neuroactive steroids. FASEB J 6:23112322.

Pfaff DW, McEwen BS (1983) Actions of estrogens and progestins on nerve cells. Science 219:808-813.

Puia G, Santi MR, Vicini S, Pritchett DR, Purdy RH, Paul SM, Seeburg $\mathrm{PH}$, Costa $\mathrm{E}$ (1990) Neurosteroids act on recombinant human GA$B_{A}$ receptors. Neuron 4:759-765.

Purdy RH, Morrow AI, Blinn JR, Paul SM (1990) Synthesis, metabolism and pharmacological activity of $3 \alpha$-hydroxy steroids which potentiate GABA-receptor-mediated chloride ion uptake in rat cerebral cortical synaptoneurosomes. J Med Chem 33:1572-1581.

Ramon y Cajal S (1911) Histologie due systeme nerveux del l'homme et vertebres. Madrid: Instituto Ramon y Cajal; (2d printing 1972).

Represa A, La Salle GL, Ben-Ari Y (1989) Hippocampal plasticity in the kindling model of epilepsy in rats. Neurosci Lett 99:345-350.

Schofield PR, Darlison MGF, Fujita N, Burt DR, Stephenson FA, Ro- 
digues H, Rhee LM, Ramachandran J, Reale V, Glencorse TA, Seeburg PH, Barnard EA (1987) Sequence and functional expression of the $\mathrm{GABA}_{\mathrm{A}}$ receptor show a ligand-gated receptor super-family. Nature 328:221-227.

Selye $H$ (1941) The anesthetic effect of steroid hormones. Proc Soc Exp Biol Med 46:116-121.

Selye $H$ (1942) The antagonism between anesthetic steroid hormones and pentamethylenetetrazol (metrazol). J Clin Endocrinol 27:10511053 .

Shingai R, Sutherland ML, Barnard EA (1991) Effects of subunit types of the cloned $\mathrm{GABA}_{\mathrm{A}}$ receptor on the response to a neurosteroid. Eur J Pharmacol 206:77-80.

Sloviter RS (1992) Possible functional consequences of synaptic reorganization in the dentate gyrus of kainate-treated rats. Neurosci Lett 137:91-96.

Smith SJ (1988) Neuronal cytomechanics: the actin-based motility of growth cones. Science 242:708-715.

Sutula T, Xiao-Xian H, Cavazos J, Scott G (1988) Synaptic reorganization in the hippocampus induced by abnormal functional activity. Science 239:1147-1150.

Suzdak PD, Swartz RD, Scholnick P, Paul SM (1986) Ethanol stimulates $\gamma$-aminobutryic acid receptor-mediated chloride transport in rat brain synaptoneurosomes. Proc Natl Acad Sci USA 83:40714075.

Tauck DL, Nadler JN (1985) Evidence of functional mossy fiber sprouting in hippocampal formation of kainic acid-treated rats. J Neurosci 5:1016-1022.
Teyler TJ, Vardaris RM, Lewis D, Rawitch AB (1980) Gonadal steroids: effects on excitability of hippocampal pyramidal cells. Science 209:1017-1020.

Thampy KG, Barnes EM (1984) $\gamma$-Aminobutyric acid-gated chloride channels in cultured cerebral neurons. J Biol Chem 259:1753-1757.

Toran-Allerand CD (1984) On the genesis of sexual differentiation of the central nervous system: morphogenetic consequences of steroidal exposure and possible role of fetoprotein. Prog Brain Res 61:63-98.

Turner DM, Ransom RW, Wang JS-J, Olsen RW (1989) Steroid anesthetics and naturally occurring analogs modulate the $\gamma$-aminobutyric acid receptor complex at a site distinct from barbiturates. J Pharmacol Exp Ther 248:960-966.

Ward MS, Nadi NS, Schaffner AE, Barker JL (1992) Developmental expression of 3-alpha hydroxysteroid oxidoreductase in rat CNS. Soc Neurosci Abstr 18:100.8

Weeks JC, Levine RB (1990) Postembryonic neuronal plasticity and its hormonal control during insect metamorphosis. Annu Rev Neurosci 13:183-194.

Weidenfeld J, Siegel RA, Chowers I (1980) In vitro conversion of pregnenolone to progesterone by discrete brain areas of the male rat. J Steroid Biochem 13:961-963.

Wieland S, Lan NC, Mirasedeghi S, Gee KW (1991) Anxiolytic activity of the progesterone metabolite $5 \alpha$-pregnan-3 $\alpha$-ol-20-one. Brain Res 565:263-268.

Wong M, Moss RL (1991) Electrophysiological evidence for a rapid membrane action of the gonadal steroid, $17 \beta$-estradiol, on CAl pyramidal neurons of the rat hippocampus. Brain Res 543:148-152. 